\title{
Landscape transformation under the Gåsbreen glacier recession since 1899, southwestern Spitsbergen
}

\author{
Wiesław ZIAJA*, Justyna DUDEK and Krzysztof OSTAFIN \\ Instytut Geografii i Gospodarki Przestrzennej, Uniwersytet Jagielloński, \\ ul. Gronostajowa 7, 30-387 Kraków, Poland \\ <wieslaw.ziaja@uj.edu.pl><justyna_dudek@wp.pl><krzysztof.ostafin@uj.edu.pl> \\ * corresponding author
}

\begin{abstract}
Landscape changes of the Gåsbreen glacier and its vicinity since 1899 are described. Maps at 1:50 000 scale of changes of the glacier's elevation and extent for the periods 1938-1961, 1961-1990, 1990-2010, and 1938-2010 are analyzed in comparison with results of the authors' field work in the summer seasons 1983, 1984, 2000, 2005 and 2008. During all the 20th century, the progressive recession of the glacier revealed in a dramatic decrease in the thickness of its lower part, with a small reduction of its area and length. However, further shrinkage produced significant shortening and reduction in area which resulted in final decline of the Goësvatnet glacial dammed lake in 2002. Hence, the lowest (and very thick, up to 150-160 m) part of the former glacier tongue and dammed lake were transformed into a new terraced river valley south of the glacier and a typical marginal zone with glacial landforms north of the glacier. Since 1961, the equilibrium line altitude of the Gåsbreen glacier has risen from $\mathrm{ca} 350$ to ca $500 \mathrm{~m}$ a.s.l. and now is located below the very steep rocky walls of the Mehesten mountain ridge, $1378 \mathrm{~m}$ a.s.l. Hence, the glacier is being fed by snow avalanches from these rocky walls and much more snow melts during the warmer summer seasons, stimulating a quicker recession of the lowest part of the glacier. This recession may be stopped only by significant climate cooling or increase in snow.
\end{abstract}

Key words: Arctic, Svalbard, landscape transformation, glacier recession, climate warming.

\section{Introduction}

Gåsbreen is an interesting glacier in the context of current landscape changes caused by the climate warming after the Little Ice Age. There are two primary reasons for that: (1) location - it is the westernmost glacier of Sørkappland (the southern peninsula of Spitsbergen), flowing west from the foot of the Mehesten rocky wall and ending on land, easy accessible from the Gåshamna anchor bay and (2) it is the glacier with the longest monitoring of all the 84 
Sørkappland glaciers; monitoring of its extent and geometry was initiated in 1899 by making a topographical map, at 1:50 000 scale, of the glacier's lower part and vicinity (Fig. 1).

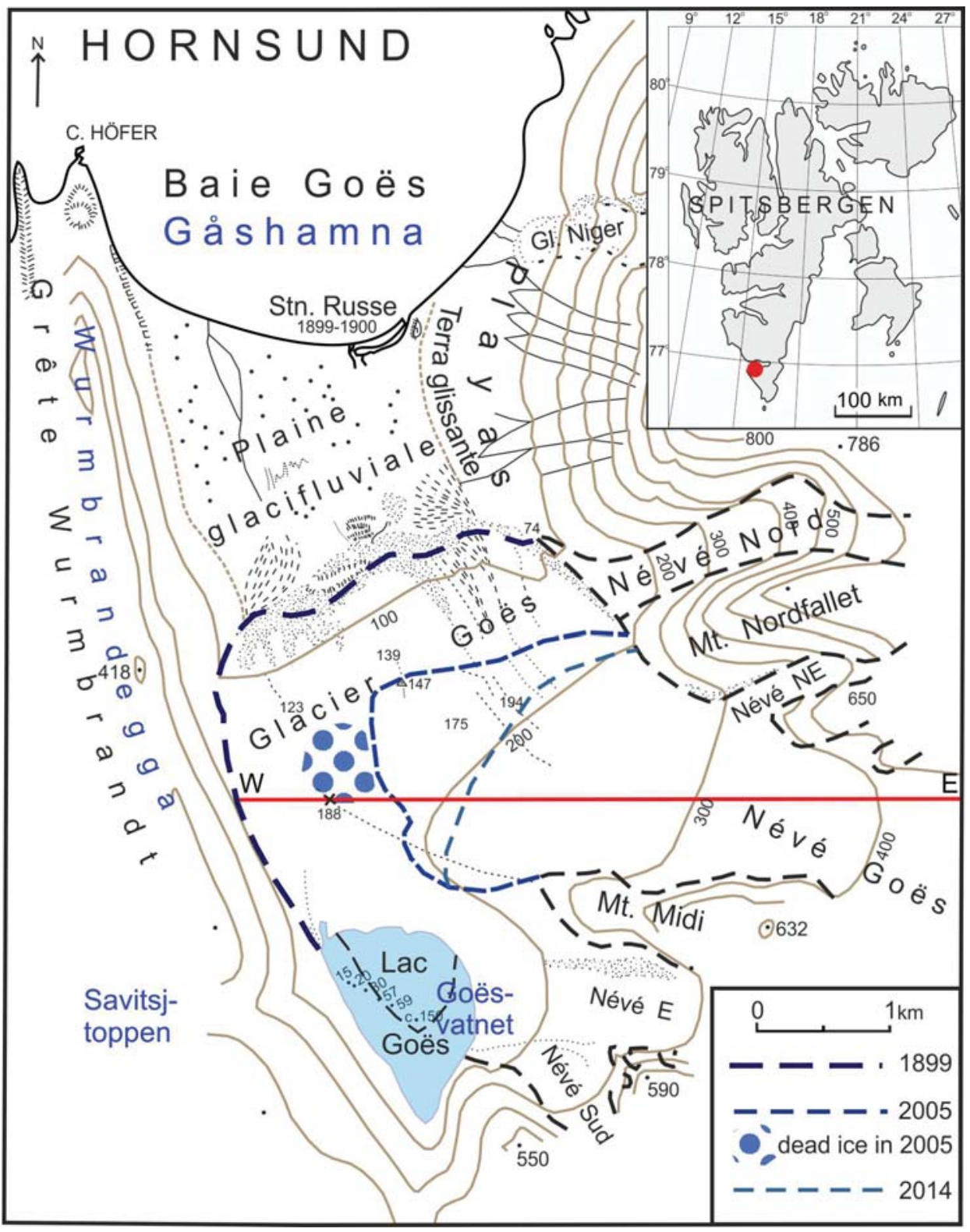

Fig. 1. Map of the Gåsbreen glacier with its vicinity made by De Geer (1923) in 1899 and redrawn by Pillewizer (1939). The extents of the glacier in 2005 and 2014 from Terra ASTER (USGS) are added. The red line on the glacier indicates the profile shown in Fig. 2. The geographical names are originally in French but four of them are also in Norwegian (in blue). 
The 1899-2010 period is an ideal time frame to outline the landscape transformation due to glacier recession conditioned by the afore-mentioned climate warming. In 1899, the glacier extent was maximum in the Little Ice Age which culminated there in the 1890s, according to different authors (e.g. Brázdil 1988; Salvigsen and Elgersma 1993; Rachlewicz et al. 2007). Since the beginning of the 20th century, climate warming resulted in a general recession of the Spitsbergen glaciers, which persists until today. Secondary cooling fluctuations in the 1940s and 1960s (evidenced e.g. by Brázdil 1988) did not change this trend.

\section{Materials and methods}

Gåsbreen, quite a big glacier (6.5 km long and 1-2 km wide in 2010), medium size in the scale of Sørkappland, has undergone this recession which was firstly slow and then accelerating, evidenced in the topographical maps relating to the following years: 1938 (Pillewizer 1939), 1961 or 1983-1984 (Barna 1987), 1990 (Schöner and Schöner 1996). These maps let us draw longitudinal hypsometric profiles of the glacier's surface (Fig. 2). The newest profiles of the lower part of the surface were surveyed by the authors with the help of both a traditional Paulin altimeter and a Garmin 12 GPS receiver during the Jagiellonian University (JU) summer expeditions of 2000, 2005 and 2008. These measurements formed the most accurate dataset providing information on changes in elevation of the glacier surface before the summer of 2010 when the last photogrammetric flight was undertaken by the Norwegian Polar Institute above the peninsula.

The afore-mentioned profiles, with results of landscape mapping of the glacier's vicinity, aerial (especially infrared from 1990 and digital from 2010) and terrestrial photographs, as well as satellite images (especially Terra ASTER from USGS) constitute a data base of glacier and terrain change.

Comparisons of the landscape state (especially the shrinking glacier's extent and topography and landforms with water bodies uncovered from under the glacier) allows demonstration of contemporary landscape transformation in the study area, which is a main objective of the paper.

Changes in the geometry of Gåsbreen were determined for the periods 1938-1961, 1961-1990 and 1990-2010. The computation was based on comparison of glacier surface area and elevation inferred from old topographic maps, aerial photographs and modern DEMs. The following four baseline datasets were used for the study:

1. The dataset for 1938 is a scale $1: 25000$ map based on terrestrial photogrammetric measurements made during the German summer expedition in 1938 (Pillewizer 1939). Co-registration of this map was performed using original map grid at $2 \mathrm{~km}$ interval. In the second phase, a transformation of the map coordinates to the WGS-1984 datum in UTM projection (Zone 33X) was performed based on a trigonometric network and the position of mountain tops in the glacier's 


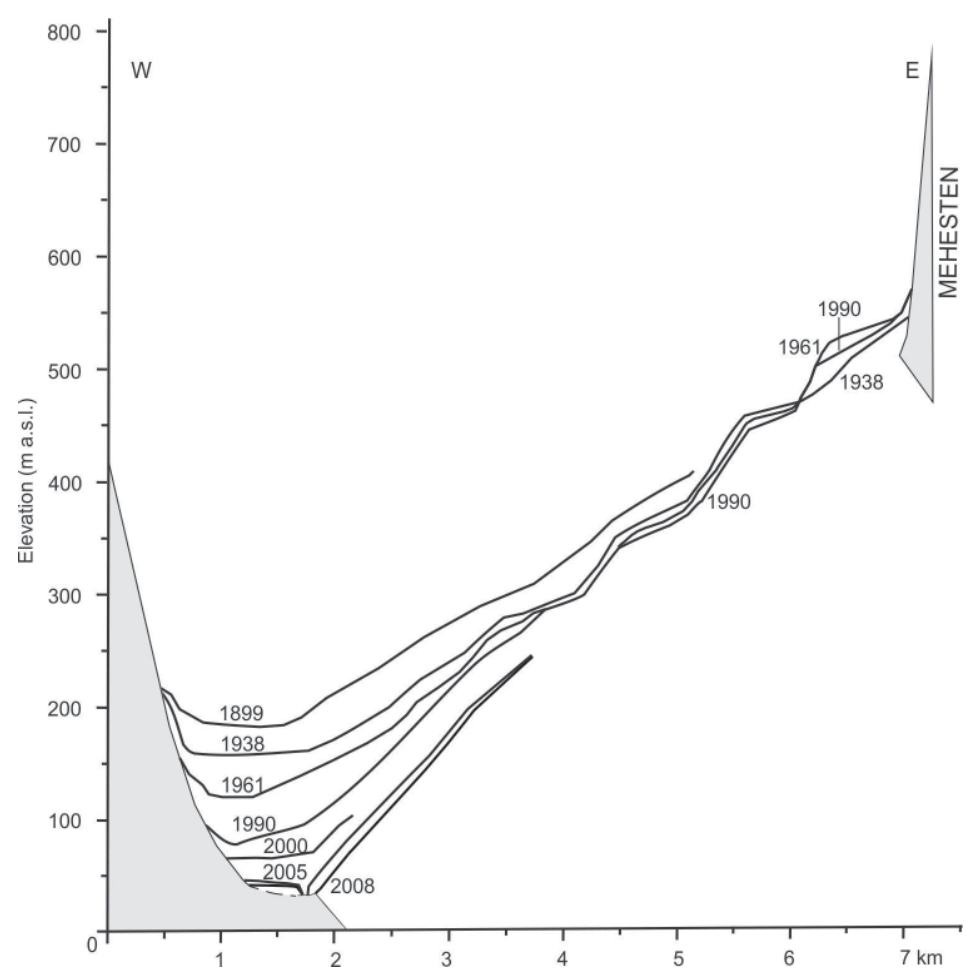

Fig. 2. Change of thickness of the Gåsbreen glacier from 1899 to 2008, based on the maps current for 1899 (De Geer 1923), 1938 (Pillewizer 1939), 1961 (Barna 1987), 1990 (Schöner and Schöner 1996), and the authors' measurements in 2000, 2005 and 2008. The profile line is shown in Fig. 1.

vicinity. Elevation points, streams and contour lines of a $20 \mathrm{~m}$ vertical interval were digitized and interpolated to a DEM at $20 \mathrm{~m}$ resolution. In the interpolation, two different techniques available in ESRI ArcGIS 10.1 software were tested: Topo to Raster tool based on the ANUDEM algorithm, considered to be the most effective for creating hydrologically correct raster surface (Hutchinson 1989), and TIN to Raster tool - a linear interpolation triangulation procedure and Triangulated Irregular Network conversion to a $20 \mathrm{~m}$ x $20 \mathrm{~m}$ regular grid. The efficiency of both methods for glaciological research has been shown by numerous authors (Kohler et al. 2007; Barrand et al. 2010; Nuth et al. 2010; Lapazaran et al. 2013). The latter method gave superior results and is used here.

The DEM created for 1938 was validated against the pre-existing 1990 elevation dataset, derived by the Norwegian Polar Institute from vertical aerial photographs. Since the map of 1938 was made on the basis of oblique photographs of lower quality, we assumed that the dataset from 1990 was more reliable, and we used it as reference data. In order to estimate the 1938 DEM's vertical accuracy, elevation differences between these years were investigated 
on stable areas not glacier-covered. In the DEM assessment, slope gradients were also taken into consideration because a significant part of the study area comprised steep slopes inclined more than $20^{\circ}$, non-representative for glacier areas. Furthermore, the areas where contour lines on the map of 1938 were marked with dashed lines were excluded from the analysis due to their large elevation uncertainty as described by Pillewizer (1939) and by Schöner and Schöner (1996). After filtering, the average elevation difference for unglaciated areas was $4.20 \mathrm{~m}$ with a standard deviation of $2.18 \mathrm{~m}$.

2. The dataset for 1961 is constructed from the topographic map sheet (Gåsbreen) at a scale of 1:25 000, edited by the Polish Academy of Sciences (Barna 1987), compiled photogrammetrically on the basis of vertical aerial photographs (scale 1:50 000, taken in summer 1961 for the Norwegian Polar Institute) and geodetic measurements carried out during the 6th Spitsbergen Expedition of the Academy in the 1983 and 1984 summer seasons. The original coordinate system of the map, based on the European Datum 1950 (ED50), was transformed to the WGS-1984 datum in UTM projection (Zone 33X). The contour lines on the map represent elevations in 1961 whereas the glacier boundary was updated to the early 1980s extent. For consistency, we digitized the glacier boundary from vertical aerial photo taken by the Norwegian Polar Institute in July of 1961. Elevation points, streams and contour lines at a $10 \mathrm{~m}$ vertical interval, derived from the map, were interpolated to the Triangulated Irregular Network and subsequently converted to a $20 \mathrm{~m}$ x $20 \mathrm{~m}$ regular grid. The average elevation difference between the 1990 and 1961 DEMs on ice-free areas with slopes inclined less than $20^{\circ}$ was 2.10 with a standard deviation of $2.82 \mathrm{~m}$.

3. The dataset for 1990 is a modern DEM with a 20 m resolution, compiled by the Norwegian Polar Institute from vertical aerial photographs at a scale 1:50 000 taken in the summer of 1990. Its vertical accuracy as estimated by its author for ice-free areas is approximately $2-5 \mathrm{~m}$, but somewhat greater elevation errors characterized ice surfaces (Terrengmodell Svalbard 2014). The boundary of Gåsbreen current for 1990 was digitized from a topographic map sheet at a scale of 1: 100000 edited by the Norwegian Polar Institute (C13 Sørkapp 2007). The map was scanned and co-registered to a common datum and projection.

4. The dataset for 2010 consists of digital aerial photographs acquired by the Norwegian Polar Institute. For this study, seven images covering Gåsbreen were processed photogrammetrically using tools available within Leica Photogrammetry Suite 2011, an extension of the Erdas Imagine 2010 software. The main processing steps for generating a DEM were image matching and elevation point cloud extraction (eATE) which were subsequently interpolated to give a DEM with a $20 \mathrm{~m}$ resolution (Terrain Prep Tool). Visual inspection of the point cloud showed lack or very low density of elevation points in areas of low radiometric contrast, shadowed or covered by clean, white snow. These areas were characterized by significant elevation errors and excluded from further 
analysis as shown in Figs 3-4. The quality of this DEM in the remaining areas was satisfying. The average elevation difference from the $1990 \mathrm{DEM}$ on the ice-free areas with slopes inclined less than $20^{\circ}$ was $-0.21 \mathrm{~m}$ with a standard deviation of $2.36 \mathrm{~m}$. The generated 2010 DEM was used to create an orthophotomap for 2010, a base layer for manual delineation of the glacier boundary.

Glacier elevation changes over the periods 1938-1961, 1961-1990,1990-2010 and 1938-2010 were estimated by differencing the created DEMs using tools of ESRI ArcGIS 10.1, giving the difference in elevation at each pixel.

\section{Results}

The specific location of the Gåsbreen glacier, which occupies a lateral valley falling westward to a main valley which runs from the south to north, has influenced both its advance during the Little Ice Age and its recession since the beginning of the 20th century. Because of its location, the glacier could not be significantly lengthened in the advance phase after its front reached the eastern slope of the Wurmbrandegga-Savitsjtoppen mountain ridge. Instead, its volume increase resulted in thickening and thus increase of its surface elevation until the end of the 19th century, and also in widening of its terminus (where the glacier could spread sideways in the wide main valley, especially to the north, i.e. down-valley).

Changes during 1899-1938. - As a result of the Little Ice Age advance, the lowest part of the glacier's terminus had become a natural dam across the main valley. The Goësvatnet ice-dammed lake developed above (south of) the dam as long as the glacier's front reached the slope of the ridge.

The first phase of the glacier recession resulted in a decrease in its thickness, i.e. lowering of its surface by $30-40 \mathrm{~m}$ in its lower part, without retreat. This glacier thinning can be seen in the comparison of its longitudinal profile and the elevation reached by its front in AD 1899 (Figs 1-2).

Changes during 1938-1961. - In 1938, the glacier's tongue reached $200 \mathrm{~m}$ a.s.l., on the eastern slope of the Wurmbrandegga-Savitsjtoppen mountain ridge which was a barrier obstructing the tongue. The tongue flowed down freely to the north, reaching below $100 \mathrm{~m}$ a.s.l. on the Gåshamnøyra lowland.

From 1938 to 1961, a significant decrease in thickness occurred in the glacier's tongue below 310-390 m a.s.l. The lower the surface altitude, the bigger the decrease. The biggest decrease, by 30-50 m, occurred at the glacier's front. In spite of that, shortening of the glacier was small $(108 \mathrm{~m})$ due to its thickness against the Wurmabrandegga-Savitsjtoppen mountain ridge (Fig. 3, Table 1). 

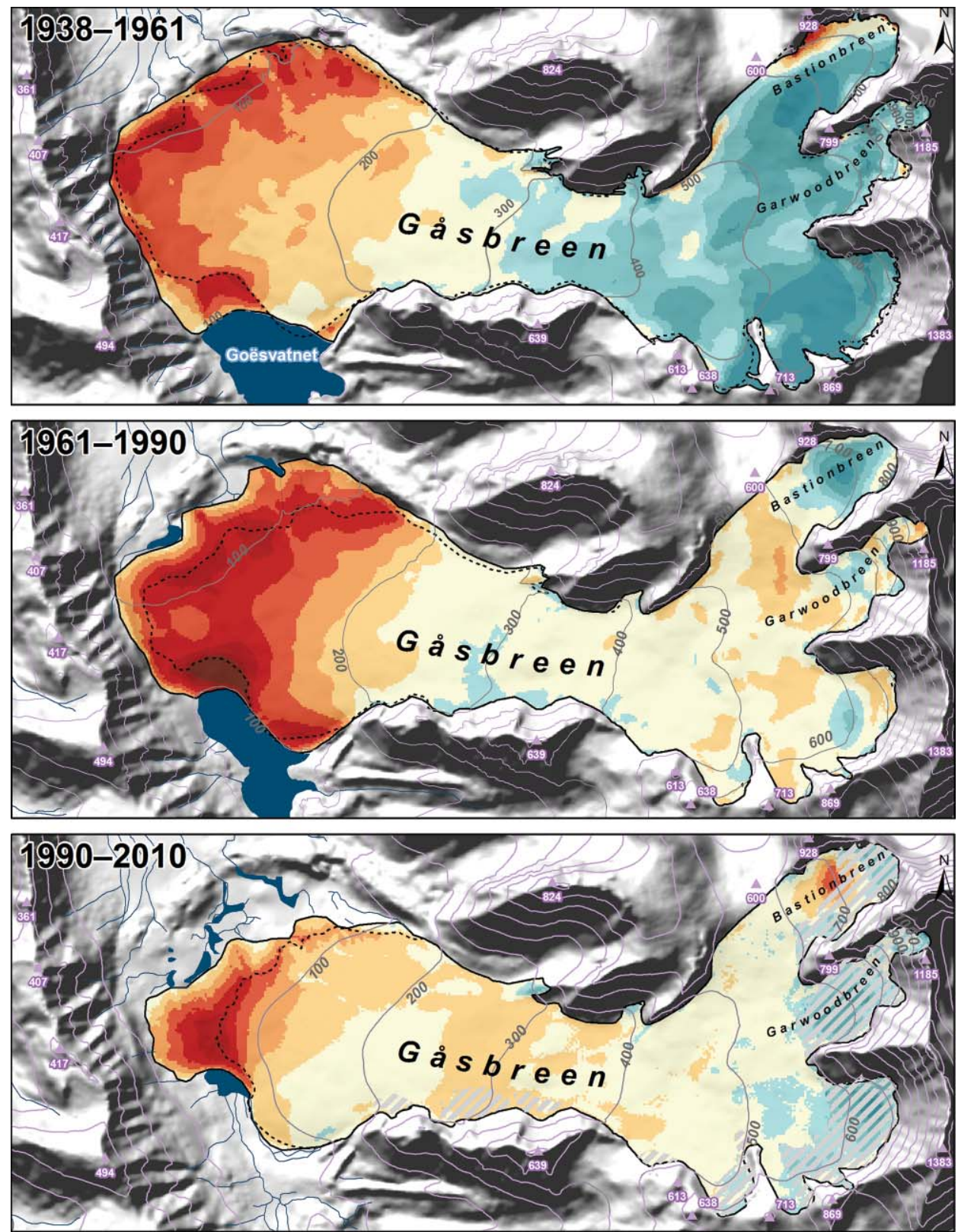

\section{Legend}

Elevation changes [m]

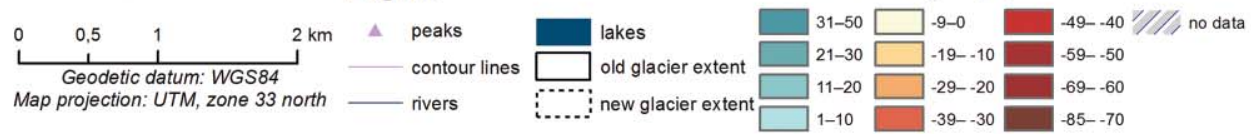

Fig. 3. Changes of the glacier's elevation and extent. Contour lines and water bodies are from the first year of each period. 


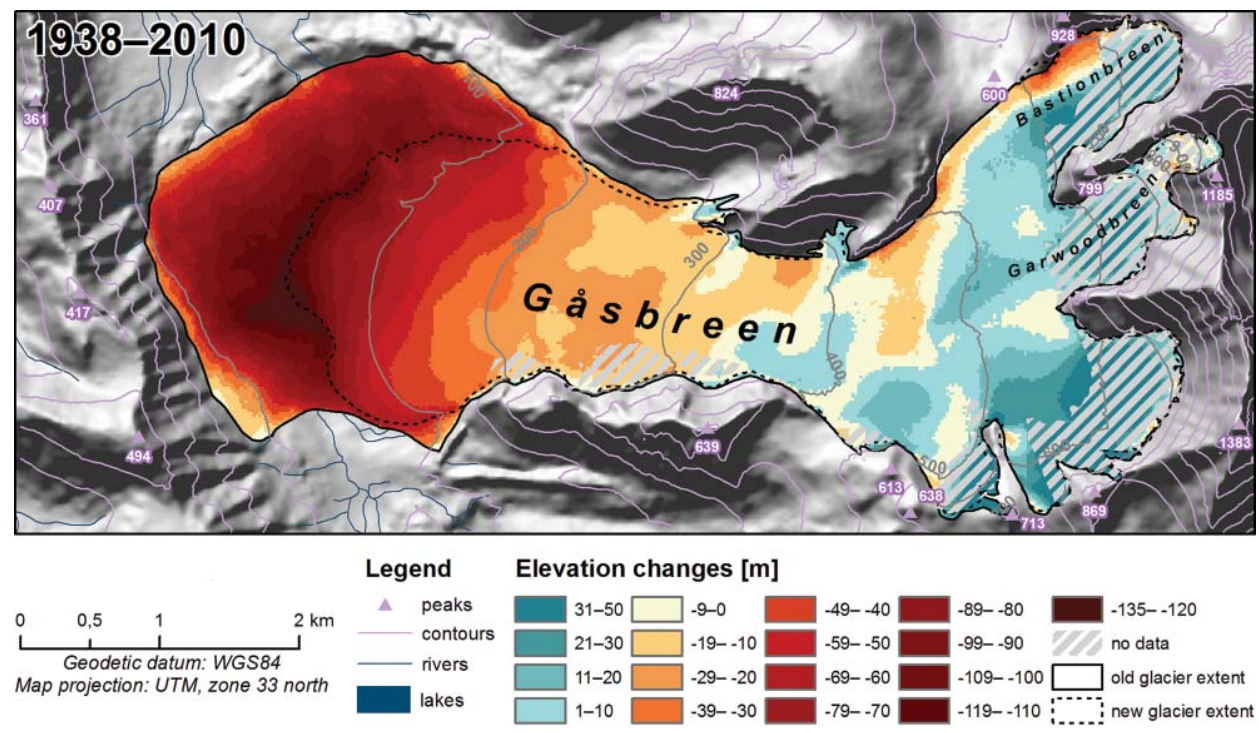

Fig. 4. Changes of the glacier's elevation and extent from 1938 to 2010. Contour lines and rivers are from 2010.

The glacier's thickness increased above 310-390 m a.s.l. This increase was greatest, 21-40 m, in its upper, but not highest, part between 500 and $650 \mathrm{~m}$ a.s.l. A much smaller increase in thickness, 1-20 m, occurred in the middle part of the glacier, from 310-390 to $500 \mathrm{~m}$ a.s.l., and in its highest part, above $650 \mathrm{~m}$ a.s.1. This increase in the glacier's thickness was also evidenced by Schöner and Schöner (1996). However, a significant thinning, 0-39 m, occurred at the upper (northern) edge of the Bastionbreen tributary glacier (Fig. 3). Hence, the equilibrium line altitude was between 310 and $390 \mathrm{~m}$ a.s.l. in both 1938 and 1961. A similar value, $c a 350 \mathrm{~m}$, was determined by the Hess method (Leonard and Fountain 2003) based on the inflection of elevation contour lines.

Changes during 1961-1990. - During this time, the glacier thinned on almost all its surface. The decrease in its thickness was greatest, $20-85 \mathrm{~m}$, below $200 \mathrm{~m}$ a.s.l. In the middle and upper parts of the glacier, this decrease was smaller: 0-19 m. A clear increase of thickness, between 1 and $50 \mathrm{~m}$, occurred in the firn field of the Bastionbreen tributary glacier above $620-650 \mathrm{~m}$ a.s.l. Apart from this, a small thickening of the glacial body, 1-20 m, occurred only in two sites of the Gåsbreen accumulation zone: in the central-northern part of the Garwoodbreen tributary glacier (at 600-700 m a.s.1.) and in the middle of the southeastern firn field (at 580-620 m a.s.1.). In spite of such a large decrease in thickness and volume, and a significant narrowing of its lowest part, the glacier was shortened by only $229 \mathrm{~m}$, and continued to function as the natural dam for the Goësvatnet lake (Fig. 3, Table 1). 


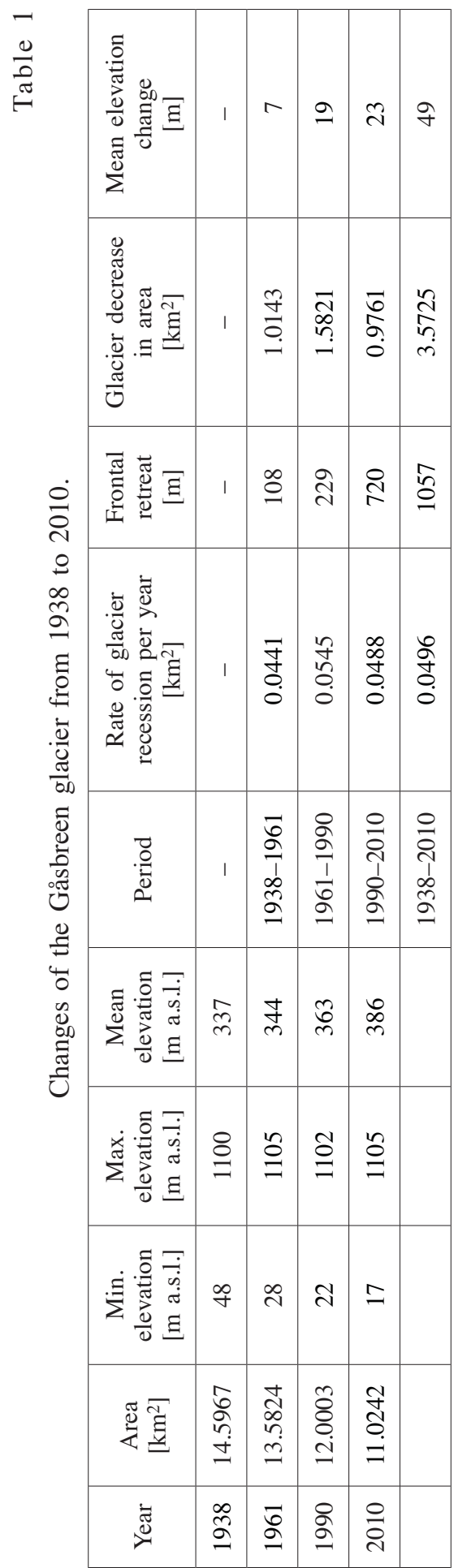


Hence, in 1990, the equilibrium line altitude was situated significantly higher than in 1961. The equilibrium line altitude could be $400-500 \mathrm{~m}$ a.s.l. according to results of analysis of the air photographs from 1990 and a field survey in the summer of 1991 (Schöner and Schöner 1996). A little bit higher value, 500-600 m a.s.l., was determined by the afore-mentioned method based on the inflection of elevation contour lines. The rise of this altitude from $c a 350$ to ca 500 m a.s.l. probably occurred in the 1970s and 1980s, because a clear (but secondary) climate cooling had occurred in Spitsbergen in the 1960s (Brázdil 1988).

Changes during 1990-2010. - In this period, the mean annual temperature and precipitation increased by $2^{\circ} \mathrm{C}$ and $60 \mathrm{~mm}$ respectively (Table 2). This led to substantial glacier change. Nuth et al. (2013) indicate that the transition in rate of the Svalbard glaciers' recession occurred about 1990.

Table 2

Changes in temperature and precipitation at the Polish Polar Station at Horsund

(13 km northwest of the Gåsbreen glacier), elaborated on the basis of data from the Institute of Geophysics, Polish Academy of Sciences, published in part by Styszyńska (2013).

\begin{tabular}{|l|c|c|}
\hline \multicolumn{1}{|c|}{ Period } & $1980-1989$ & $2000-2009$ \\
\hline Mean annual temperature $\left({ }^{\circ} \mathrm{C}\right)$ & -5.2 & -3.15 \\
\hline Mean annual sum of precipitation $(\mathrm{mm})$ & 390.5 & 451.3 \\
\hline
\end{tabular}

The ice thickness decreased on all the glacier's surface below $700 \mathrm{~m}$ a.s.l., apart from the southeastern firn field. The greatest decrease, up to $59 \mathrm{~m}$, was at the glacier's front. Total retreat of the glacier was $720 \mathrm{~m}$ during this period (Fig. 3, Table 1). The course of the glacier recession occurred in two stages in terms of landscape-environmental consequences.

In the first stage, the thinning of the glacier's tongue was slow and did not result in its significant shortening or shrinking. The glacier-dammed lake continued to persist until the summer 2001 when was visible the last time in the satellite image Landsat (USGS). Earlier, the lake was observed by the JU Expedition in 2000 (Fig. 5).

In the second stage, the glacier retreated a lot, by $c a 500 \mathrm{~m}$, and shrank significantly in its frontal part, which resulted in the disappearance of the ice dam. In the summer seasons of 2002-2004, the lake has not already existed, what is clearly visible in the satellite images Landsat and Terra ASTER (USGS). During the next JU expedition in the summer of 2005, the glacial-dammed lake did not exist and its former floor was transformed into the terraced floor of a new river valley (Fig. 5). This transformation, which included formation of the river terraces and waterfalls, and the beginning of plant succession on the erosion terraces, was 

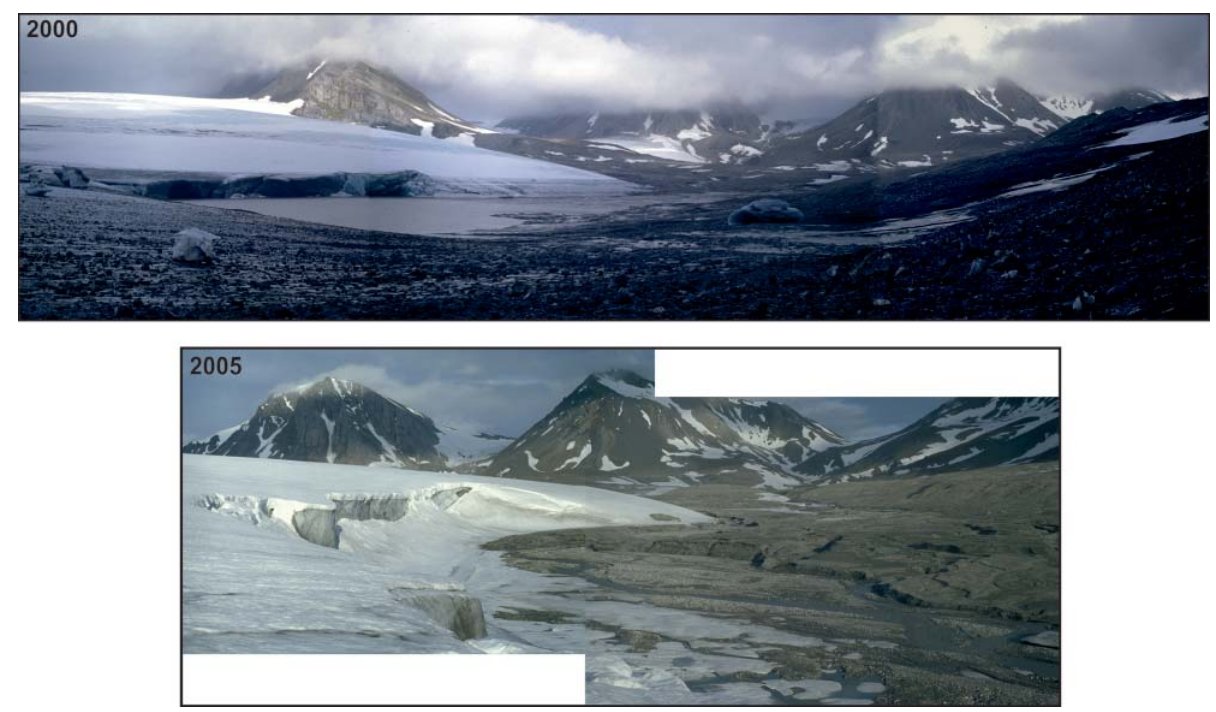

Fig. 5. View from the lowest part of the Gåsbreen glacier to SE. Upper photo: Goësvatnet, the ice dammed lake on July 24, 2000, one day after a rapid drainage of the majority of its water through the subglacial tunnel. The lake's water table reached 1-2 $\mathrm{m}$ below the uppermost surface of the glacial dam, what is evidenced by deposits and growlers on this surface in the foreground. Lower photo: the former lake's bottom reshaped by fluvial processes.

continuing in the summer of 2008, as observed during the next JU expedition (Figs 6-7). Hence, the second stage of the glacier's recession, with a completely new landscape development, began in 2002 and persists until today.

The tendency of changes in the glacier's uppermost part is unknown due to the lack of data for 2010. A clear though small increase in the glacier's thickness, 1-10 m, occurred from 1990 to 2010 in its southeastern (mostly shadowed) firn field between 500 and $600 \mathrm{~m}$ (Fig. 3). This was caused by a significant increase in precipitation, mainly snow at this altitude (Table 2), related to higher evaporation (from the sea surface mainly) because of the climate warming. It is rather sure that there was also an increase in the glacier's thickness above $600 \mathrm{~m}$ (the higher the altitude, the more snow in precipitation), what was also observed there during the JU expeditions in the summer seasons of 2005 and 2008. A clear decrease in thickness, 1-30 m, occurred only on the part of Bastionbreen glacier exposed to the south.

\section{Recapitulation}

During the observation period from 1899 to 2008, a decrease in the glacier's thickness by $150-160 \mathrm{~m}$ has occurred in its lowest part between $188 \mathrm{~m}$ a.s.l. and 32-34 m a.s.l. - the altitudes of the lake's dam built of the glacier's ton- 

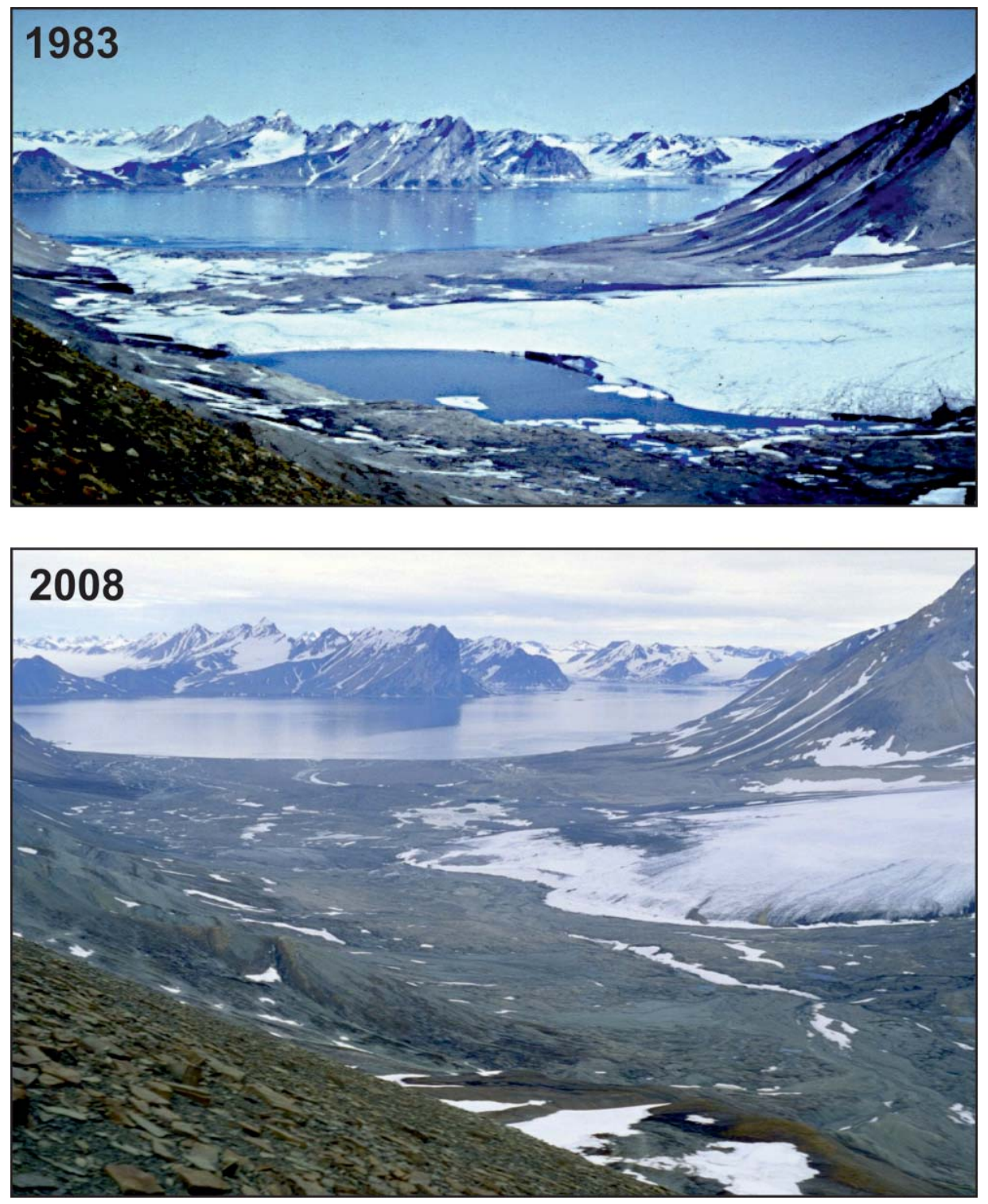

Fig. 6. Landscape changes near the lower part of the Gåsbreen glacier: the Goësvatnet glacialdammed lake (which still existed in 2001) disappeared in 2002 because of the glacier's recession. Gåsbreen glacier became much shorter and no longer dams up the valley. View to the north.

gue in 1899 (De Geer 1923) and the glacier's front in the same place in 2008 surveyed by GPS receiver and altimeter by the authors (Figs 1-2).

From 1938 to 2010, the ice thickness decreased over the entire glacier surface below $350 \mathrm{~m}$ a.s.l. (reaching $350 \mathrm{~m}$ just in 2010). The biggest decrease, up to 

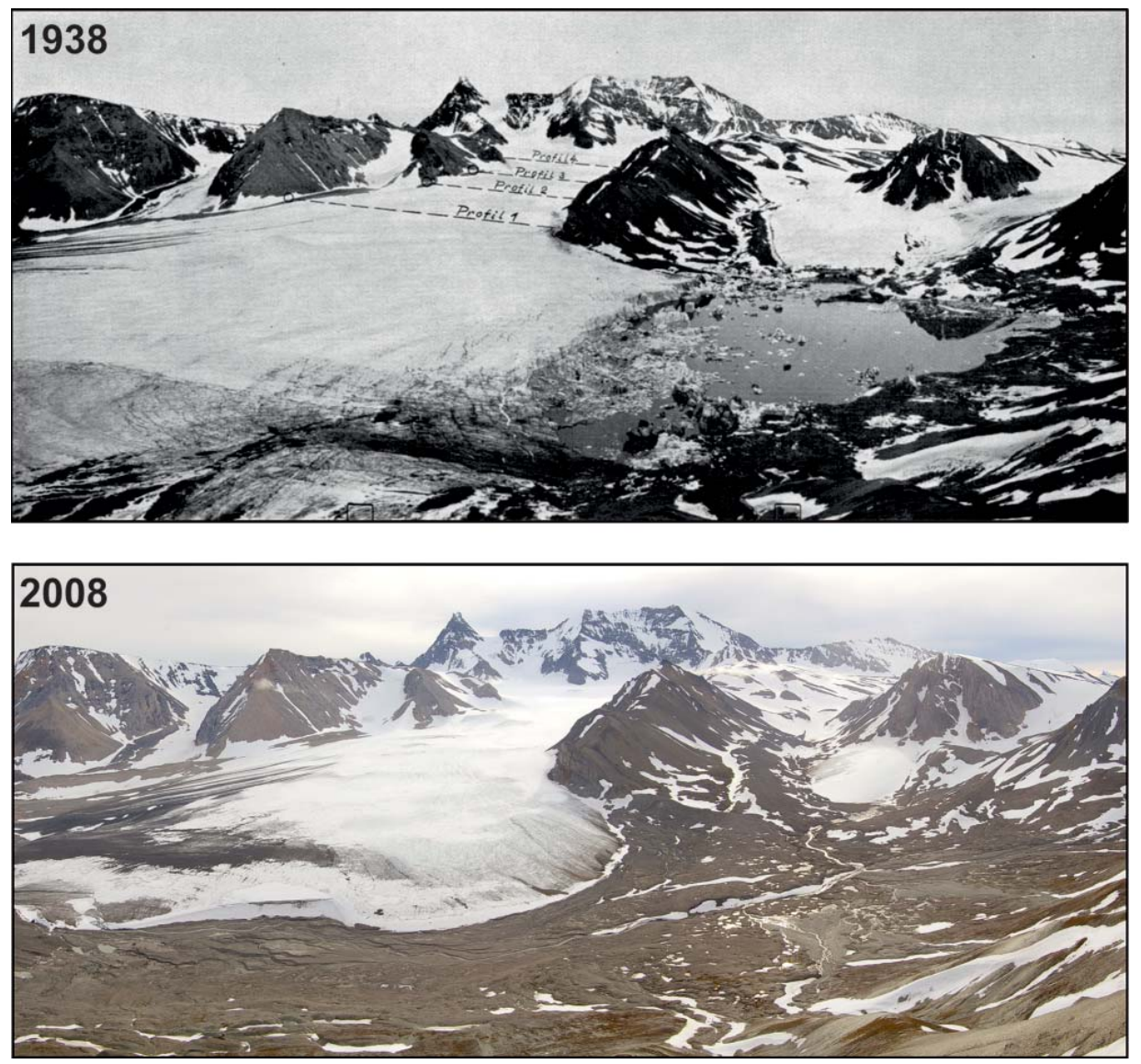

Fig. 7. Landscape changes around the upper part of the Gåsbreen glacier (with the Hornsundtind mountain group, $1431 \mathrm{~m}$, in the background) and the main valley south of the glacier: Gåsbreen glacier's recession resulted in (1) great changes in terrain relief in valleys, (2) disappearance of the Goësvatnet glacial-dammed lake, and (3) formation of a new terraced river valley. View from the Savitsjtoppen's top flattening ( $c a 490 \mathrm{~m}$ a.s.l.) to the east. Upper photo: Pillewizer (1939).

$120 \mathrm{~m}$, occurred in the former frontal part of the glacier, transformed into the new river valley, mountain slopes and marginal zone (build of moraine ridges with ice cores and sandurs). $3.57 \mathrm{~km}^{2}$ were abandoned by the glacier there. The glacier's surface above $350 \mathrm{~m}$ a.s.l. did not decrease at all, and a clear increase in the ice thickness, up to $50 \mathrm{~m}$, was evidenced in the majority of this part of the glacier, apart from the northern glacier's side exposed to the south, which slightly thinned (Figs 4, 7). Hence, there was a dramatic landscape transformation of the lower part of the glacier and a smaller change above $350 \mathrm{~m}$ a.s.l. (Figs 6-7). This is connected with the afore-mentioned rise of the equilibrium line altitude.

The glacier's recession led to the lowering of the natural glacial dam. Hence, the highest (summer) water table of the ice-dammed Goësvatnet lake underwent 
a progressive lowering during the 20th century. This highest water level used to occur at the beginning of each summer season until opening a well-visible (e.g. in 1984 and 2000) subglacial out-flowing channel (and perhaps smaller subglacial or englacial channels). Afterwards, during the summer, the lake used to shrink (Grześ and Banach 1984; Schöner and Schöner 1997), as observed by the JU Expedition in 1984. The lake was last observed in summer 2000 (Fig. 5) when it firstly reached a level 1-2 m below the glacial dam's top at the altitude 65-66 m a.s.l. (at the lowest point of the dam's top surface, $c a 0.5 \mathrm{~km}$ from the glacier front), and afterwards, on July 23rd, flowed in a flood wave to the coastal plain due to the opening of a subglacial channel.

The ice thickness in the lower part of the glacier decreased most quickly at the beginning of the 21st century. In 2005, destruction of the aforementioned subglacial channel was evidenced, after decline of its roof due to ablation lowering the glacier surface by 22-23 $\mathrm{m}$ in the period 2000-2005 (from 65-66 to $43 \mathrm{~m}$ a.s.l. at the lowest point of the glacier tongue's upper surface) and next by $10 \mathrm{~m}$ in $2005-2008$ (from 43 to $32-34 \mathrm{~m}$ ). This channel was transformed into a narrow valley with vertical ice slopes: the right slope being a part of the glacier front, and the left slope cut in a dead ice patch (up to 20 and $10 \mathrm{~m}$ high in 2005 and 2008). The flat bottom of this valley, 10-15 m wide, is taken by the river which carries water from the left side and front of the glacier, and also from the upper (southern) part of the main valley. After 2008, the slopes of the narrow valley became gentler due to progressive ablation of the glacier's front and declining of the dead ice patch. This dead ice patch (the former lowest part of the glacier) situated to the west of this valley at the foot of the mountain slopes, has undergone rapid ablation and become smaller and smaller since at least 2005 (Fig. 8).

A further decrease in the glacier thickness began to result in its shortening, i.e. so-called frontal retreat, with accelerated areal recession (including surface ablation) of the glacier's lower part, especially on the sides. The glacier's marginal zone, formed after the Little Ice Age (since the beginning of the 20th century), is divided into two parts by the glacier tongue and the patch of dead ice.

The retreat (narrowing) of the glacier is mainly of the "frontal" type from the left (southern) side of its lower part, near the former Goësvatnet lake, i.e. the glacier's edge undergoes ablation without burying bodies of dead glacial ice in morainic or glacifluvial material. This new part of the marginal zone, appearing after decline of the dammed lake, i.e. after 2001, consists mainly of the former lake bottom (of several levels) which has been transformed into the river bed, and the frontal ice-cored moraine ridges which undergo rapid erosion at the foot of the mountain slope (Fig. 8).

From the right side of the glacier's lower part, just above the coastal plain, the progressive glacier recession is of the "areal" type: the slowly narrowing 


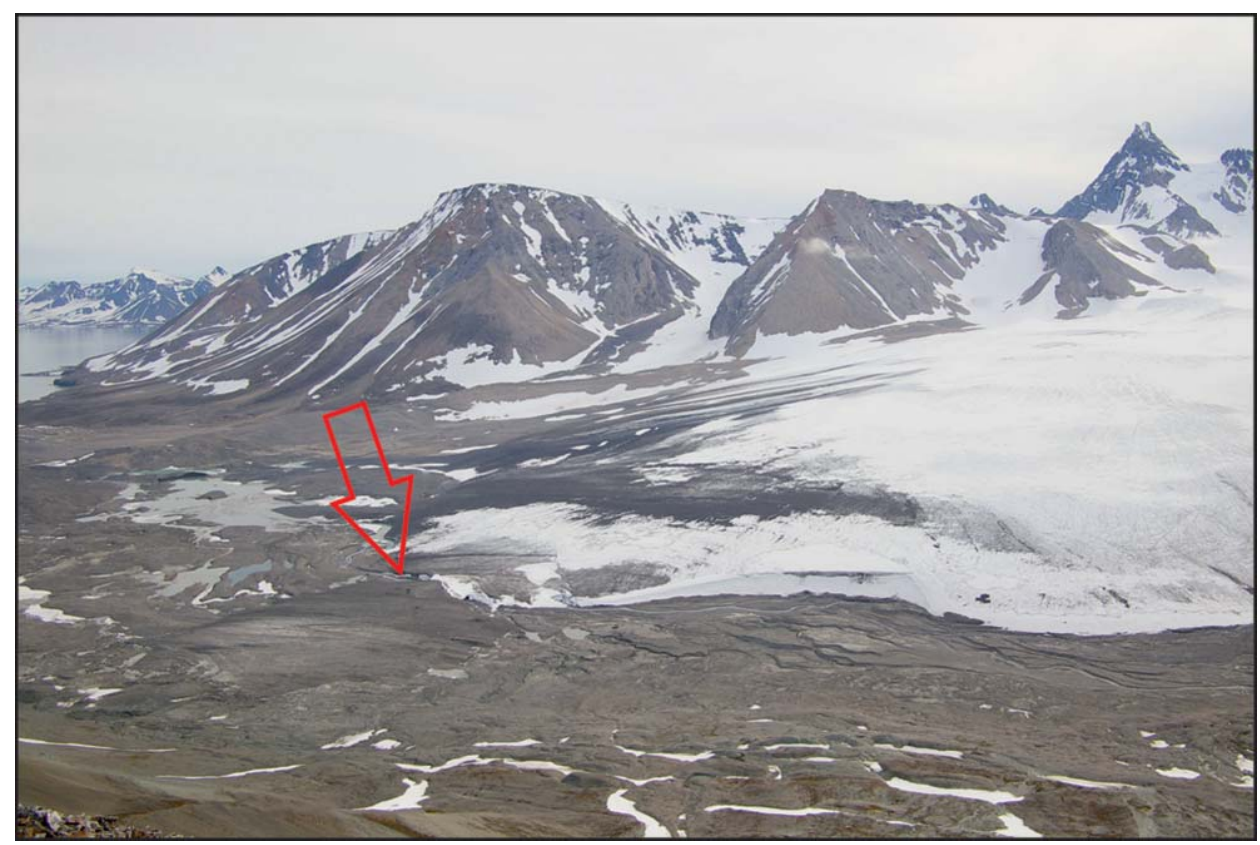

Fig. 8. View from the Savitsjtoppen's top flattening ( $c a 490 \mathrm{~m}$ a.s.1.) to NE in 2008: the former westernmost part of the Gåsbreen glacier changed into the patch of dead ice (covered with black moraine) divided from the glacier's front by the open river channel (subglacial until 2000) indicated by the arrow. The former (until 2001) bottom of the lake basin changed into the terraced river valley, visible left (south) of the glacier (to the right of the photo). The right (northern) part of the glacier's marginal zone which consists of moraine ridges, kames, sandurs and water bodies is visible right (north) of the glacier (to the left of the photo). All the marginal zone is built of dead ice covered with glacial and fluvial deposits.

glacier tongue is being progressively covered by moraine or glacifluvial material, inward from the outside. Almost all the contemporary marginal zone of the glacier is formed on dead glacial ice. Covered by a thin layer of deposits, this melts very slowly. Ice-cored moraine ridges, kames, sandurs and proglacial river beds predominate there (Fig. 8). In this part of the marginal zone, a significant transformation of the landforms and deposits previously described (Szupryczyński 1960, 1963; Jewtuchowicz 1962, 1965; Jania et al. 1981) has occurred, leading to lowering of the older ice-cored morainic ridges and hills or kames by at least several meters, and to a decrease in their slope gradient.

The steep western slopes of Mehesten above $600 \mathrm{~m}$ a.s.l. have been mostly free of glaciers since at least 1938. Above $600 \mathrm{~m}$ a.s.1., only the cirque floors were filled or covered by glaciers: Bastionbreen up to $800 \mathrm{~m}$, Garwoodbreen up to $1100 \mathrm{~m}$, and the southeastern firn field up to $800 \mathrm{~m}$, except for big snow cones piled up by avalanches above the glacier there (Figs $3-4,7,9$ ). 


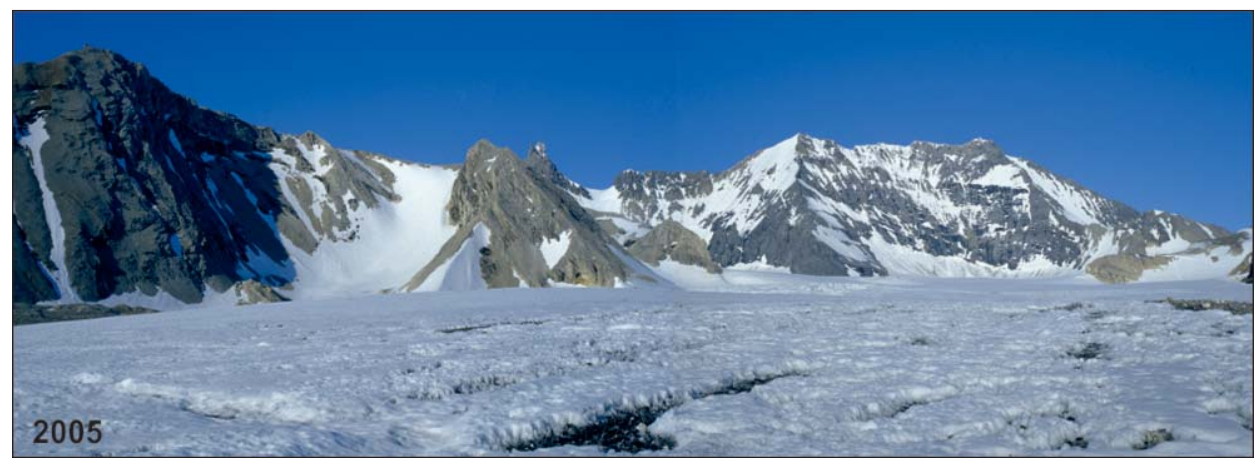

Fig. 9. The middle and upper part of the Gasbreen glacier at the foot of the Mehesten rocky wall (free of ice from 600 to $1378 \mathrm{~m}$ a.s.l.) in 2005, at the right. Tributary glaciers of Gåsbreen, flowing from the northeast - at the middle and left. The photo was taken from $c a 250 \mathrm{~m}$ a.s.l.

\section{Conclusions}

The contemporary climate warming (since the beginning of the 20th century) resulted in a general recession of glaciers. During all the 20th century (from 1899 to 2000 precisely), the progressive net wastage of Gåsbreen glacier resulted mainly in a dramatic decrease in the thickness of its lower part, with only small reduction of its area and length. However, such a prolonged shrinkage prepared for a significant shortening and areal reduction of its lower part since the beginning of the 21st century, resulting in the final decline of the Goësvatnet glacial-dammed lake in 2002. This coincides with glacial recession in other Svalbard areas: Błaszczyk et al. (2009) described a great retreat of the Svalbard tidewater glaciers, Ziaja and Dudek (2011) evidenced a quick retreat of the Olsokbreen tidewater glacier in the southwestern Sørkappland, and Nuth et al. (2013) noted an extensive retreat of nearly all tidewater and land based glaciers in Svalbard between 1990 and 2010.

In this way, a significant transformation of landscape structure resulted in a great change in functioning of the environment: there is a new river valley replacing the lowest (and once very thick) part of the former glacier tongue and the dammed lake.

The wider and wider marginal zone of the Gasbreen glacier is being transformed more and more intensively. Its left (southern) part undergoes first of all fluvial and slope processes, whereas its right (northern) part is shaped mainly by ablation of dead glacial ice. In spite of that, this dead ice still composes a majority of the volume of the accumulative glacial landforms.

The equilibrium line altitude of the Gåsbreen glacier has risen from $c a 350$ to $c a 500 \mathrm{~m}$ a.s.l. and coincides mostly with the upper part of the glacier being located well below the snow line. This is because of gravitational falling of snow 
from the very steep rocky walls of the Mehesten mountain ridge, which rises to $1378 \mathrm{~m}$ a.s.l. and thus overtops the snow line. Hence, the glacier is being fed by snow avalanches from these rocky walls. However, in such a situation, much more snow melts during summer seasons, especially these warmer ones, stimulating a quicker recession of the lowest part of the glacier. This recession may be stopped only by significant climate cooling or increase in snow precipitation.

Acknowledgements. - Field investigations were carried out within the project No. N305 035634 Changes of the western Sørkapp Land natural environment under the global warming and human activity since the 1980s, and the earlier projects financed by the Polish Ministry of Science and Higher Education. The reviewer Ian S. Evans from Durham University in England is acknowledged for assistance in proofreading the text. As it refers to Figs 3 and 4, the authors thank sincerely to Christopher D. Clark, University of Sheffield, for enabling of using his GIS laboratory and Timothy James, University of Swansea, for his help and guidance in the photogrammetric processing of digital images. The work was partly conducted in the Geography Department, University of Sheffield, owing to the scholarship in the frame of the project "Society-Technologies-Environment" realized by the Jagiellonian University within the Human Capital Operational Programme. We wish to thank reviewers Mauri S. Pelto from Nichols College in Dudley, Massachusetts and Grzegorz Rachlewicz from Adam Mickiewicz University in Poznań for their helpful suggestions.

\section{References}

BARNA S. 1987. Spitsbergen, Gåsbreen, 1:25 000 (topographic map). Instytut Geofizyki PAN (Institute of Geophysics, Polish Academy of Sciences), Warszawa.

BARRAND N.E., JAMES T.D. and MURRAY T. 2010. Spatio-temporal variability in elevation changes of two High-Arctic valley glaciers. Journal of Glaciology 56: 771-780.

BŁASZCZYK M., JANIA J.A. and HAgEN J.O. 2009. Tidewater glaciers in Svalbard. Recent changes and estimates of calving fluxes. Polish Polar Research 30: 85-142.

BRÁZDIL R. 1988. Variation of air temperature and atmospheric precipitation in the region of Svalbard. In: Results of investigations of the geographical research expedition Spitsbergen 1985. Folia Facultatis Scientiarum Naturalium Universitatis Purkynianae Brunensis (Brno), Geographia 24: 285-323.

C13 Sørkapp 2007. Svalbard 1:100 000 (topographic map). Norsk Polarinstitutt, Troms $\varnothing$.

DE GEER G. 1923. Plan öfver det svebsk-ryska gradmätningsnätet på Spetsbergen efter nyaste sammanstäld Maj 1900 1:1000000 (topographic map). In: Mesure D’un Arc de Méridien au Spitzberg, Entr. en 1899-1902, Description Topographique de la Région Explorée. Géologie. Aktiebolaget Centraltryckeriet, Stockholm (in Swedish and French).

GRZEŚ M. and BANACH M. 1984. The origin and evolution of the Goes Lake in Sørkapp Land, Spitsbergen. Polish Polar Research 5: 241-253.

HUTCHISON M.F. 1989. A new procedure for gridding elevation and stream line data with automatic removal of spurious pits. Journal of Hydrology 106: 211-232.

JANIA J., LENTOWICZ Z., SZCZYPEK T. and WACH J. 1981. Szkic geomorfologiczny rejonu Gåsdalen (południowy Spitsbergen). In: A. Jahn, J. Jania and M. Pulina (eds) VIII Sympozjum Polarne, Materiały 1, Referaty i Komunikaty, Instytut Geografii, Uniwersytet Śląski, Klub Polarny PTG, Sosnowiec: 119-128 (in Polish). 
JEWTUCHOWICZ S. 1962. Studia z geomorfologii glacjalnej północnej części Sörkappu. Acta Geographica Lodziensia 11: 75 pp. (in Polish).

JewTUCHOwiCZ S. 1965. Description of Eskers and Kames in Gåshamnöyra and on Bungebreen, South of Hornsund, Vestspitsbergen. Journal of Glaciology 5: 719-725.

Kohler J., James T.D., Murray T., Nuth C., BrandT O., BARRAND N.E., AAS H.F. and LuCKMAN A., 2007. Acceleration in thinning rate on western Svalbard glaciers. Geophysical Research Letters 34, doi: 10.1029/2007GL030681.

Lapazaran J., Petlicki M., Navarro F., Machio F., Puczko D., GŁowacki P. and Nawrot A., 2013. Ice volume changes (1936-1990-2007) and ground-penetrating radar studies of Ariebreen, Hornsund, Spitsbergen. Polar Research 32, doi: http://dx.doi.org/10.3402/polar.v32i0.11068.

LEONARD K.C. and FOUNTAIN A.G. 2003. Map-based methods for estimating glacier equilibriumline altitudes. Journal of Glaciology 49: 329-336.

Nuth C., Kohler J., KÖNig M., von Deschwanden A., Hagen J.O., KäÄB A., Moholdt G. and PETTERSSON R. 2013. Decadal changes from a multi-temporal glacier inventory of Svalbard. The Cryosphere 7: 1603-1621.

Nuth C., Moholdt G., Kohler J., Hagen J.O. and Kä̈̈B A. 2010. Svalbard glacier elevation changes and contribution to sea level rise. Journal of Geophysical Research - Earth Surface 115, doi: 10.1029/2008JF001223.

PILlEWIZER W. 1939. Die Kartographischen und Gletscherkundlichen Ergebnisse der Deutschen Spitzbergenexpedition 1938. Petermanns Geographische Mitteilungen (Gotha) 238: 46 pp.+2 maps (in German).

RaChlewicz G., SZCZUCiŃSKI W. and Ewertowski M. 2007. Post-"Little Ice Age" retreat rates of glaciers around Billefjorden in central Spitsbergen, Svalbard. Polar Research 28: 159-186.

SAlvigSEN O. and Elgersma A. 1993. Radiocarbon dating of deglaciation and raised beaches in north-western Sørkapp Land. Zeszyty Naukowe Uniwersytetu Jagiellońskiego, Prace Geograficzne 94: 39-48.

SCHÖNER M. and SCHÖNER W. 1996. Photogrammetrische und glaziologische Untersuchungen am Gåsbre (Ergebnisse der Spitzbergenexpedition 1991). Geowissenschaftliche Mitteilungen, Schriftenreihe der Studienrichtung Vermessungswesen der Technischen Universität Wien 42: 120 pp.+2 maps (in German).

SCHÖNER W. and SCHÖNER M. 1997. Effects of glacier retreat on the outbursts of Goësvatnet, southwest Spitsbergen, Svalbard. Journal of Glaciology 43: 276-282.

STYSZYŃSKA A. 2013. Results of observations. In: A.A. Marsz, A. Styszyńska (eds) Climate and climate change at Hornsund, Svalbard. Gdynia Maritime University, Gdynia: 321-365.

SZUPRYCZYŃSKI J. 1960. The Marginal Zone of the Gås Glacier (Sörkappland, Southern Spitsbergen). Bulletin de l'Académie Polonaise des Sciences, Série des Sciences Géologiques et Géographiques 8: 313-319.

SZUPRYCZYŃSKI J. 1963. Rzeźba strefy marginalnej i typy deglacjacji lodowców południowego Spitsbergenu. Prace Geograficzne, Instytut Geografii PAN, 39: 162 pp. (in Polish).

Terrengmodell Svalbard (S0 Terrengmodell) 2014. Troms $\varnothing$, Norway: Norwegian Polar Institute. https://data.npolar.no/dataset/dce53a47-c726-4845-85c3-a65b46fe2fe.

USGS: HTTP://EARTHEXPLORER.USGS.GOV/

ZIAJA W. and DUDEK J. 2011. Glacial recession. In: W. Ziaja (ed.) Transformation of the natural environment in Western Sørkapp Land (Spitsbergen) since the 1980s. Jagiellonian Uniwersity Press, Kraków: 51-60. 